\title{
Metallic foreign body on the optic nerve head
}

\author{
Aditi Mehta (ㄷ, ' Chirag Jain 다, ${ }^{2}$ Nazia Anjum, ${ }^{1}$ Ramandeep Singh Virk ${ }^{3}$
}

${ }^{1}$ Advanced Eye Centre, Post Graduate Institute of Medical Education and Research, Chandigarh, India

${ }^{2}$ Radiodiagnosis and Imaging, Post Graduate Institute of Medical Education and Research, Chandigarh, India ${ }^{3}$ ENT, Post Graduate Institute of Medical Education and Research, Chandigarh, India

\section{Correspondence to} Dr Ramandeep Singh Virk; virkdoc@hotmail.com

Accepted 6 October 2020
Check for updates

(C) BMJ Publishing Group Limited 2020. No commercial re-use. See rights and permissions. Published by BMJ.

To cite: Mehta $A$, Jain $C$, Anjum $\mathrm{N}$, et al. BMJ Case Rep 2020;13:e238443. doi: $10.1136 /$ bcr-2020 238443

\section{DESCRIPTION}

A middle-aged man presented with sudden painful loss of vision in the right eye following ocular trauma while working in a nut and bolt factory. At the time of trauma, he was not using protective safety glasses. On examination, he denied perception of light in the right eye, and had a visual acuity of $6 / 6$ in the left eye. A $3 \mathrm{~mm}$ scleral laceration was noted near the 12 o'clock limbus; posterior segment details were not visible due to total hyphaema. An A/B scan ultrasonography revealed distorted right globe with a high-amplitude spike of a hyperechoic foreign body on the optic nerve head (figure 1A). Orbital CT confirmed the presence of a hyperdense metallic foreign body on the optic nerve head (figure 1B,C). Despite counselling, the patient refused surgery. He was advised to avoid undergoing MRI scans in the future in view of the metallic foreign body.

The Birmingham Eye Trauma Terminology System is a useful, standardised method for classifying severe globe trauma. ${ }^{1}$ Penetrating and perforating globe injuries from missiles and projectiles may lead to entrapped foreign bodies within the globe, ocular coats or the orbit. A particularly rare scenario is lodgement in the optic nerve head, leading to profound vision loss, as seen in our case. Associated optic neuropathy, retinal vascular compromise and siderosis bulbi can be additional mechanisms of vision loss. ${ }^{2}$ Surgical management involves removal of the foreign body and meticulous repair of the wound. However, removal of a large $(>1 \mathrm{~mm})$ central foreign body is seldom useful in regaining vision. ${ }^{3}$ In such situations, patients should be counselled regarding the risks of sympathetic ophthalmia and siderosis bulbi and also advised to avoid future MRI of the head and neck, lest it dislodges the metallic foreign body intracranially.

Occupational eye injuries may result in 'preventable' blindness with an immense socioeconomic impact for the worker as well as the industry. A study from East India on 784 patients reported metallic foreign bodies
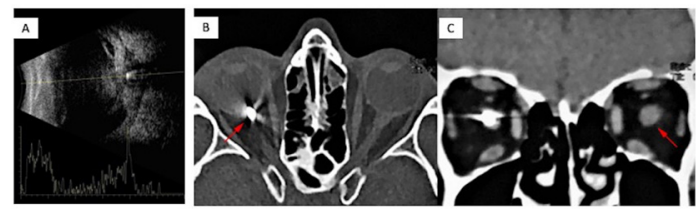

Figure 1 (A) Ultrasound of the right orbit demonstrates distorted globe architecture with high-amplitude spike of hyperechoic foreign body on the optic nerve head. (B, C) CT scan of the orbit shows hyperdense metallic foreign body on the optic nerve head (arrow in axial section; B) vis-à-vis normal left optic nerve head (arrow in coronal section; C).

\section{Learning points}

- Foreign bodies should be suspected in all patients presenting with globe injury to the emergency department.

- The initial investigation of choice is always a CT and never an MRI, especially if the nature of the foreign body (metallic vs non-metallic) is not known.

- Occupational eye injuries are preventable with use of proper safety glasses; sensitisation of workers and ensuring compliance are paramount.

as the most common cause of occupational eye injury. Lack of safety training and non-compliance with use of safety glasses were associated risk factors. ${ }^{4}$ Another study, from Norway, reported a significant reduction from 6.09 to 0.42 injuries per million working hours after implementation of mandatory eye protection. ${ }^{5}$ Compliance to protective eyewear is sometimes limited due to poor fit, blurring of vision, fogging and reduced field of view. A study based on the Victorian Injury Surveillance System reported poor compliance with safety eyeglasses in persons involved in the automotive industry and specifically for the tasks of hammering. They also reported that correct use of safety eyewear could have prevented $>60 \%$ of injuries. ${ }^{6}$

Loss of vision from occupational injuries can have devastating psychological consequences and may even result in loss of livelihood. ${ }^{7}$ Kofi Annan, the former Secretary General of the United Nations, has rightly stated: "Health and safety at work is not just sound economic policy, it is a basic human right."

Contributors AM: concept, patient management, manuscript preparation. CJ: concept, patient management, manuscript editing. NA: patient management, manuscript editing. RSV: concept, design, supervision, manuscript editing.

Funding The authors have not declared a specific grant for this research from any funding agency in the public, commercial or not-for-profit sectors.

Competing interests None declared.

Patient consent for publication Obtained.

Provenance and peer review Not commissioned; externally peer reviewed.

ORCID iDs

Aditi Mehta http://orcid.org/0000-0003-0891-8169

Chirag Jain http://orcid.org/0000-0001-9674-9371

\section{REFERENCES}

1 Kuhn F, Morris R, Witherspoon CD, et al. The Birmingham eye trauma terminology system (BETT). J Fr Ophtalmol 2004;27:206-10.

2 Zinn KM. Removal of an intraocular foreign body from the optic nerve head. Am J Ophthalmol 1980;90:317-25. 
3 Runyan TE. Concussive and penetrating injuries of the globe and optic nerve. CV Mosby Company, 1975.

4 Kundu A, Roy KK, Nazm N, et al. An epidemiological report of occupational ocular injury in eastern part of India. Int I Contemp Med Res 2017:4:1516-8.

5 Bull N. Mandatory use of eye protection prevents eye injuries in the metal industry. Occup Med 2007:57:605-6.
6 Fong $L P$, Taouk $Y$. The role of eye protection in work-related eye injuries. Aust N Z J Ophthalmol 1995;23:101-6.

7 Thompson GJ, Mollan SP. Occupational eye injuries: a continuing problem. Occup Med 2009;59:123-5.

8 Hoskin AK, Mackey DA, Keay L, et al. Eye injuries across history and the evolution of eye protection. Acta Ophthalmol 2019;97:637-43.

Copyright 2020 BMJ Publishing Group. All rights reserved. For permission to reuse any of this content visit https://www.bmj.com/company/products-services/rights-and-licensing/permissions/

BMJ Case Report Fellows may re-use this article for personal use and teaching without any further permission.

Become a Fellow of BMJ Case Reports today and you can:

- Submit as many cases as you like

- Enjoy fast sympathetic peer review and rapid publication of accepted articles

Access all the published articles

Re-use any of the published material for personal use and teaching without further permission

Customer Service

If you have any further queries about your subscription, please contact our customer services team on +44 (0) 2071111105 or via email at support@bmj.com.

Visit casereports.bmj.com for more articles like this and to become a Fellow 